\title{
Pemanfaatan Social Media oleh Praktisi Public Relations di Yogyakarta
}

\author{
Hanindyalaila Pienrasmi \\ Alumnus Pascasarjana Ilmu Komunikasi, \\ Fakultas Imu Sosial dan Ilmu Politik, Universitas Gadjah Mada Yogyakarta
}

\begin{abstract}
Social media has changes the way public relations practitioners in doing their jobs related to communicate with the public, how to communicate both individually and at the corporate level. Social media become a challenge for practitioners to improve their technical and managerial abilities as a professional to deak with the development of new technology. Practitioners continue to know more about social media in order to optimize utilization and help the company to establish a better relationship with the publics.

Based on in-depth interviews with public relations practitioners in Yogyakarta, it was found that practitioners are already utilizing social media in supporting the activities of public relations communication functions in the company. In this research whole practitioners has been used social media for branding activities and dissemination of information about company's marketing. In addition, most practitioners have also been utilizing social media as a medium to communicate with the publics in a two-way conversation and began to engage in it. Some of the practitioners also began to involve social media in monitoring issues and crisis communication and dissemination of information about the activities of corporate social responsibility and social campaigns that is undertaken by the company.
\end{abstract}

Keywords: internet, social media, Public Relations practicioner

\section{A. Latar Belakang}

Kemajuan teknologi terus berkembang dan mengalami perubahan seiring dengan perkembangan zaman, salah satunya adalah internet. Menurut Rob Franklin et al (2009: 114) kehadiran internet membawa dampak tersendiri bagi dunia bisnis maupun institusi media, termasuk pula bagi dunia public relations. Selain itu pada dunia bisnis dan public relations juga membawa dampak tersendiri sebagai saluran komunikasi baru dalam berhubungan dengan para publiknya. Praktisi public relations memiliki saluran langsung dalam berkomunikasi dengan publiknya tanpa harus termediasi melalui awak jurnalis bahkan lebih dari itu internet juga mampu merubah hubungan komunikasi antara keduanya. Selain itu internet memiliki beberapa keunggulan dibandingkan media lain, seperti yang dikemukakan Asheroft, Macintosh dan Sallot (Lindic, 2006: 2):

"the internet offers several advantages when compared to the other media such as speed of communication, almost immediate product delivery, interactivity, customization, and personalization: it can improve productivity, efficiency and issues management. The internet also provides an ideal forum of group communication and interaction. 
Internet didefinisikan oleh Tom Kelleher (2007: 5) adalah sebagai jaringan global yang dapat diakses oleh seluruh publik. Jaringan ini merupakan suatu sistem yang menghubungkan berbagai komputer, kabel, dan perangkat kabel serta nirkabel yang terhubung satu sama lain untuk membantu orang dalam pertukaran informasi di seluruh dunia. Perkembangan internet terus terjadi hingga akhirnya melahirkan suatu teknologi baru yakni Web 2.0 yang memperkenalkan dunia pada Web Sosial dan merupakan sebuah medium yang digunakan seorang dalam berkomunikasi dengan komunitas online yang mereka kéhendaki. Salah satu bentuk aplikasi dari teknologi Web 2.0 adalah social media. Liu, Arnett, Capella, \& Beatty (McLennan \& Howell, 2010: 11) menyarankan bahwa jejaring media sosial dapat digunakan oleh organisasi dalam membangun hubungan dengan publiknya dan memberikan berbagai macam informasi dan layanan yang berhubungan dengan organisasi kepada berbagai publik yang baik secara langsung maupun tidak langsung berhubungan dengan organisasi.

Grunig (2009:1) juga mengemukakan bahwa kehadiran social media telah mengubah cara para praktisi dalam berpikir dan melaksanakan praktikpraktiknya dan beranggapan bahwa hal ini merupakan sebuah kekuatan revolusioner dalam bidang public relations. Grunig juga meyakini bahwa dengan mengoptimalkan potensi yang dimiliki oleh social media maka praktik public relations akan lebih mendunia, lebih strategis, semakin bersifat komunikasi dua arah dan interaktif, simetris atau dialogis dan lebih bertanggungjawab secara sosial. Hal ini cukup dapat mendasari bahwa pada era baru ini social media dapat dijadikan sebagai salah satu media yang digunakan dalam strategi public relations dalam berkomunikasi dengan publiknya.
Pertumbuhan pengguna internet di Indonesia menurut hasil survey Asosiasi Penyelenggara Jaśa Internet Indonesia (APJII) hingga pada triwulan pertama di 2013 ini telah mencapai lebih dari 63 juta orang atau sekitar melebihi dari 24,32 persen dari jumlah penduduk Indonesia dan bahkan diprediksi hingga akhir tahun mencapai 80 juta penduduk. ${ }^{\text {I }}$ Menurut data ini Indonesia berhasil menduduki peringkat ketiga negara pengakses internet di kawasan Asia. Lebih lanjut bahwa pengguna internet yang paling banyak ditemui di Indoriesia adalah pengakses situs jejaring sosial. ${ }^{2}$

Diakui oleh koordinator I APJI Yogyakarta bahwa di tahun 2012 trafik penggunaan internet di Yogyakarta mengalami peningkatan yang pesat3. Hal ini salah satunya dipicu oleh faktor meningkatnya jumlah pengguna media sosial di Yogyakarta serta ketersedian berbagai pilihan gadget yang mudah didapatkan dan perlombaan tarif paket data operator yang semakin kompetitif. Berdasarkan pada data tersebut maka media sosial tidaklah lagi menjadi hal yang asing bagi warga Yogyakarta. Adanya peningkatan pada jumlah pengguna media sosial di Yogyakarta menjadi landasan peneliti untuk melakukan penelitian mengenai pemanfaatan media sosial khususnya pada praktisi public relations di Yogyakarta. HaI ini mengingat bahwa perkembangan public relations global telah memiliki perhatian pada kehadiran media sosial dan peneliti mencoba

1

http://www.apiii.or.id/v2/index.php/read/article/api ii-at-media/169/-akhir-2013-pengguna-internetcapai-80-iuta.html diakses pada tanggal 14 Juni 2013

${ }^{2}$ http://bisnis.news.viva.co.jd/news/read/395508nielsen--ieiaring-sosial-turun--Dengguna-internet-

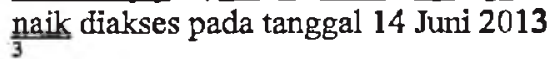

htto:/inet.detik.com/read/2011/07/22/123424/1686 887/398/media-sosial-picu-pertumbuhan-trafikinternet-iogia diakses tanggal 4 September 2013 
mencari tahu tentang fenomena yang sama pada praktisi public relations tingkat lokal. Peneliti melalui penelitian ini mencari tahu tentang sejauh mana praktisi public relations di Yogyakarta memanfaatkan media sosial dalam melaksanakan fungsi-fungsi komunikasinya. Bersama dengan itu pula mencari tahu bagaimana cara praktisi mengelola media sosial dalam mendukung fungsi-fungsi komunikasi tersebut. Selain itu pula peneliti juga menggali informasi mengenai kendala yang dihadapi oleh praktisi dalam memanfaatkan media sosial.

\section{B. Kerangka Pemikiran}

Merujuk pada apa yang dikatakan oleh Grunig dan Hunt dalam Grunig (1992: 4), mendefinisikan public relations sebagai berikut "management of communication between an organization and its publics". Berdasar pada definisi ini Grunig mencoba menggambarkan dua fungsi komunikasi yang berkaitan erat pada bidang public relations. Fungsi yang pertama adalah manajemen komunikasi. Manajemen komunikasi pada hal ini dimaknai tidak hanya mengenai teknik atau strategi bagaimana berkomunikasi atau kegiatan yang hanya meliputi program-program seperti media relations dan publisitas. Manajemen komunikasi meliputi keseluruhan atas kegiatan perencanaan, pelaksanaan dan evaluasi komunikasi pada organisasi, baik yang ditujukan pada publik eksternal dan internal. Publik dalam hal ini adalah kelompok yang mempengaruhi kemampuan organisasi dalam mencapai tujuannya. Pada fungsi manajemen komunikasi, public relations berperan pada level managerial role yang memiliki peran pada perencana dan pengambilan keputusan dalam strategi komunikasi yang dibuat.
Fungsi yang kedua adalah mengenai komunikasi organisasi. Grunig mendefinisikannya sebagai sistem komunikasi yang dikelola oleh organisasi, khususnya komunikasi antar setiap unit dalam organisasi, yang sengaja dirancang oleh para ahli komunikasi. Seperti halnya bagaimana pimpinan puncak, para manager dan pegawai biasa saling berkomunikasi satu sama lainnya dalam sebuah organisasi. Namun tidak menutup kemungkinan bahwa komunikasi organisasi tidak hanya mencakup area internal tetapi juga eksternal. Dalam melangsungkan kegiatan komunikasi tersebut tentunya para praktisi public relations membutuhkan suatu medium dalam menyebarluaskan informasi dari organisasi kepada publik dan sebaliknya untuk dapat menjaring opini publik terhadap organisasi. Media massa menjadi salah satu medium atau saluran komunikasi yang diandalkan oleh para praktisi public relations terutama dalam hal berkaitan dengan tujuan publisitas.

Seiring dengan perkembangan teknologi maka lahirlah era yang memperkenalkan dunia kepada media komputer dan teknologi internet. Kehadiran kedua media ini telah membuka peluang terjadinya komunikasi oleh siapapun, dimanapun dan kapanpun tanpa mengenal batas ruang dan waktı. Internet secara tidak langsung telah mengubah pandangan perusahaan dalam hal berkomunikasi dengan publik. Sejalan dengan hal ini Cutlip (2006: 228) juga menemukan perubahan pada public relations atas kehadiran media ini bahwa salah satu keuntungan terbesar dari internet sebagai medium public relations adalah kemampuannya untuk memberikan akses langsung dan cepat kepada khalayaknya, dan karenanya lebih unggul daripada media konvensional. 
Tom Watson dan Paul Noble (2007: 199) mengungkapkan bahwa online public relations merupakan usaha untuk mengikat orang-orang dalam komunikasi timbal balik sehingga pada akhirnya mereka menjadi pihak pendukung bagi organisasi. Semakin organisasi mendapatkan komentar yang baik dari berbagai orang maka akan semakin mudah untuk membuat yang lain percaya kepada organisasi. Namun hal ini yang perlu menjadi perhatian tersendiri bagi public relations agar terus memantau alur informasi pada era internet. Hal ini dikarenakan bahwa setiap orang dapat mengemukakan opininya kepada organisasi melalui internet secara langsung tanpa dapat tersaring terlebih dahulu.

Menurut Grunig (2009: 13), media baru juga dapat digunakan oleh public relations untuk kepentingan-kepentingan berikut, seperti media digital dapat digunakan untuk melakukan programprogram komunikasi. Program-program tersebut antara lain meliputi program komunikasi berhubungan dengan media, berhubungan dengan pelanggan, berhubungan dengan rekan kerja, berhubungan dengan komunitas, berhubungan dengan anggota organisasi non profit, hubungan dengan para donor, hubungan dengan alumni, berhungunan dengan pemerintah. Hal tersebut dilakukan semata untuk menciptakan hubungan dengan publik. Selanjutnya media baru dapat digunakan untuk melakukan scanning lingkungan. Scanning lingkungan disini memiliki pengertian untuk mendeteksi potensipotensi masalah dan isu-isu yang berkembang yang terkait dengan organisasi. Penggunaan situs pencari seperti Google dapat membantu praktisi untuk menemukan persoalan dengan memasukkan kata-kata kunci yang berhubungan dengan isu-isu berkaitan dengan organisasi. Media digital dapat berfungsi sebagai media pengawasan (monitoring) terhadap lingkungan sekeliling organisasi secara lebih baik.

Kemudian media baru juga dapat digunakan untuk segmentasi stakeholder dan publik. Segmentasi dilakukan dengan identifikasi dampak konsekuensi atau potensi dari konsekuensi kebijakan manajemen terhadap karyawan, pelanggan dan pemilik modal. Phillips dan Young dalam Grunig (2009: 14) menekankan bahwa menjadi suatu hal yang penting untuk mensegmentasi stakeholders dan publik guna memahami perbedaan cara berkomunikasi mereka kepada organisasi dan dapat memungkinkan terjadinya komunikasi dengan mereka melalui media baru. Identifikasi dapat dilakukan dengan menggunakan media digital sebagai data base.

Media baru juga dapat digunakan dalam mengantisipasi isu dan krisis. Setelah melakukan segmentasi pada stakeholder maka selanjutnya sudah dapat memulai mengidentifikasi isu yang sedang berekembang dan memprediksi krisis yang akan mugkin terjadi. Media seperti website dan blog dapat digunakan untuk program penanganan pada komunikasi isu dan krisis. Media baru juga dapat digunakan untuk mengukur hubungan dan reputasi. Melalui analisis isi media baru, akan dapat diukur hasil dari program komunikasi yang dilakukan lewat media sosial. Pengukuran reputasi yang sederhana dapat dilakukan dengan mencermati data-data yang bisa diakses lewat situs pencarian seperti Google. Terakhir adalah media baru dapat digunakan pula untuk evaluasi program yang dapat dilakukan dengan memberikan perangkat evaluasi yang sederhana seperti melakukan analisis konten online pada media baru, untuk mengukur kognisi, sikap dan perilaku. 
Social media merupakan bentuk dari sebuah penggambaran perkembangan teknologi yang memungkinkan terjadinya kegiatan pertukaran berbagai konten informasi, baik dapat berupa opini-opini, wawasan, pengalaman dan pandanganpandangan baik yang bersifat, audio, visual bahkan audiovisual. Hal ini tentu saja dapat dimanfaatkan oleh public relations dalam menyebarkan informasi kepada publiknya lebih efisien, efektif dan substansial. Solis (2009: xvii) mendefinisikan social media sebagai sebuah bentuk demokratisasi dari isi pesan dan merupakan fenomena perubahan pada aturan permainan pada proses menemukan dan menyebarkan informasi (termasuk di dalamnya menciptakan dan berbagi isi pesan). Social media menggambarkan suatu pergeseran dari mekanisme penyiaran menuju ke arah maný-to-many model, yang berakar pada format percakapan antara para komunikator dan para komunikan dengan menggunakan media sosial. Semua orang melalui media sosial yang menggunakan internet dalam memfasilitasi dapat berbagi pemikiran, pendapat serta keahliannya ke seluruh pelosok dunia tanpa batasan ruang dan waktu.

Safko \& Brake dalam Mc Lenan dan Howel (2010: 12) mendefinisikan social media dengan menekankan pada "aktifitas, kegiatan, dan perilaku pada suatu komunitas yang terdiri dari berbagai kumpulan orang yang bersatu secara online untuk berbagi informasi, pengetahuan, dan pendapat dengan menggunakan media percakapan". Media percakapan merupakan aplikasi berbasis web yang dapat memungkinkan untuk menciptakan dan mentransmisi konten secara lebih mudah baik dalam bentuk kata-kata, foto, video dan audio. Kedua definisi tersebut fokus pada perilaku dan interaksi yang terbangun antara individu, yang mana, kedua hal tersebut menjadi tujuan mereka dalam menggunakan media sosial.

Valentini dan Kruckeberg (2011) telah mengidentifikasi perbedaan utama antara media baru dan media sosial. Pada media baru merupakan sebuah bentuk inovasi berbasis pada lingkungan teknologi digital yang dapat memungkinkan seseorang untuk dapat hadir dalam berbagai bentuk kegiatan yang melintasi ruang dan waktu, sedangkan media sosial adalah lingkungan sosial online yang memungkinkan orang untuk terlibat dalam berbagai hubungan, misalnya, pekerjaan, kepentingan pribadi, dan kebutuhan spiritual. Media baru mengizinkan publik untuk memberikan kebebasan pada pencarian terhadap informasi dan cara menyebarkannya dengan memberikan pilihan audio, visual dan teks publikasi sebagai cara -cara yang dapat digunakan/dipilih oleh pengguna internet. Sedangkan pada media sosial dituntut untuk adanya keterlibatan berbagai pihak dalam membangun suatu tingkatan tertentu pada aspek interaktivitas dan partisipasi diantara sesama pengguna.

Amy Reitz (2012) dalam "Social Media's Function Organizations: A Functional Analysis Approach" mengemukakan empat fungsi social media yang dapat diterapkan pada hubungan komunikasi antara organisasi dan publiknya berdasarkan pada berbagai penelitian terkini dalam literatur bidang public relations, seperti mempertahankan identitas organisasi, kesempatan dalam membangun hubungan, kemampuan untuk mengontrol manajemen isu, dan kesempatan untuk mempromosikan CSR. Social media dapat membantu organisasi dan stakeholder menciptakan dan memelihara identitas organisasi yang kuat. Social media yang bersifat interaktif dapat memberikan kesernpatan pada publik dalam memberikan kontribusi dan 
membentuk identitas organisasi dengan menyampaikan pesan informasi secara lebih berkala dan terbuka dari sebelumnya.

Social media dapat mendukung manajemen isu dalam suatu organisasi. Hal ini dapat dimanfaatkan organisasi dalam pengambilan keputusan kebijakan dengan memonitoring dan mengevaluasi hal-hal yang diperlukan dengan melihat pada interaksi yang terjadi pada publik. Organisasi juga dapat memprediksikan hal-hal yang mungkin akan menyerang dengan secara proaktif bertanya mengenai opini dan reaksi publik tentang suatu isu tertentu. Komunikasi dua arah yang bersifat langsung dan seketika pada social media dapat dimanfaatkan organisasi dalam memonitor opini dan reaksi publiknya secara lebih terbuka dan cepat. Isu dan reaksi publik yang muncul dapat diredakan dengan memberikan konfirmasi kebenaran dan menggalang dukungan emosional pada publik. Social media juga dapat dimanfaatkan oleh organisasi untuk menyebarluaskan misi dan nilai CSR yang dilaksanakan pada strategi organisasi. Organisasi dapat memanfaatkan social media untuk menginformasikan publik mengenai berbagai event, kampanye dan kegiatan lainnya yang berkaitan dengan CSR organisasi.

\section{Metodologi Penelitian}

Berdasarkan metode yang digunakan, penelitian ini menggunakan metode kualitatif deskriptif. Penelitian deskriptif yang bersifat kualitatif yaitu peneliti berusaha untuk menggali lebih dalam dan merupakan metode yang di dalam penelitiannya tidak mencari atau menjelaskan hubungan, tidak menguji hipotesis atau membuat prediksi tetapi menggambarkan pengamatan secara langsung dan melukiskan gejala berdasarkan fakta-fakta yang ada dan bagaimana adanya. Pada hakikatnya penelitian kualitatif merupakan penelitian yang bermaksud untuk memahami fenomena tentang apa yang dialami oleh subjek penelitian misalnya perilaku, persepsi, motivasi, tindakan, dan lain-lain secara holistik, dan dengan cara deskripsi dalam bentuk kata-kata dan bahasa, pada suatu konteks khusus yang alamiah dan dengan memanfaatkan berbagai metode ilmiah (Moleong, 2005: 6). Rumusan masalah pada penelitian ini, yakni: Bagaimana Praktisi Public Relations di Yogyakarta memanfaatkan kehadiran social media dalam melaksanakan fungsi komunikasi. Hasil penelitian ini berusaha untuk memaparkan beberapa poin berikut, yakni untuk mengetahui sejauh mana pemanfaatan social media serta mengetahui bagaimana pengelolaan serta kendala dan manfaat pada social media yang dilakukan oleh praktisi public relations di Yogyakarta.

Penelitian ini di laksanakan di Provinsi Daerah Istimewa Yogyakarta. Pemilihan DIY sebagai lokasi penelitian karena merupakan salah satu provinsi di Indonesia yang sudah mulai memanfaatkan kehadiran new media dalam menunjang kemajuan kehidupan masyarakatnya. Pada penelitian ini menggunakan teknik penarikan purposive sampling, atau disebut juga judgmental sampling yang digunakan dengan menentukan kriteria khusus terhadap sampel, terutama yang dianggap ahli. Sampel penelitian ini adalah para praktisi public relations yang bekerja di wilayah DIY dan tergabung dalam persatuan Kapurel (Keluarga Public Relations Yogyakarta). Sebagai usaha pengayaan awal peneliti telah membagikan kuesioner pengantar untuk memetakan praktisi yang sudah menggunakan media sosial dalam praktik kerjanya. Kernudian dari hasil pemetaan tersebut maka praktisi menghubungi praktisi yang bersangkutan menanyakan kesediaannya untuk melakukan wawancara yang lebih 
mendalam. Berdasar dari proses tersebut peneliti mendapatkan sepuluh nara sumber, dengan rincian satu nara sumber dari perusahaan klinik kecantikan, satu praktisi dari institusi media, tiga praktisi dari usaha rumah makan dan lima praktisi dari usaha perhotelan.

\section{Hasil Penelitian dan Analisis}

\section{Arti Penting Media Sosial bagi Praktisi}

Berdasarkan dari wawancara kepada para praktisi ketika ditanyakan mengenai tanggapan mereka dengan adanya kehadiran media sosial dalam menunjang aktivitasnya maka secara keseluruhan praktisi menyambut baik dan antusias perihal dalam pemanfaatannya. Bahkan beberapa diantaranya mengungkapkan keoptimisan mereka dengan adanya media sosial membuka peluang yang lebih baik kepada praktisi untuk terus memperbaiki strategi mereka dalam menjalankan tugas-tugasnya. Praktisi mengatakan bahwa media sosial adalah media yang baru dan tantangan tersendiri bagi dirinya karena memiliki karateristik yang berbeda dari media tradisional. Kehadiran media baru merupakan pertanda terjadinya pergeseran dari era sebelumnya yang menghadirkan cara baru dalam berkomunikasi, bersosialisasi, dan menginformasikan visi misi secara real time.

Praktisi meyakini bahwa kehadiran media sosial membawa kemudahan bagi praktisi dalam melakukan aktifitas komunikasi dengan publiknya, memberikan ruang yang lebih untuk terjadinya interaksi yang melibatkan adanya umpan balik. Praktisi juga memanfaatkan media sosial sebagai alat pemantauan baik untuk memantau respon, positioning dan juga mensegmentasi publiknya. Media sosial memfasilitasi terjadinya pemberian respon yang cepat baik dalam penyebaran informasi dari perusahaan maupun respon yang didapat dari publik. Seluruh praktisi menyetujui bahwa kepopuleran media sosial di masa kini memberikan keuntungan tersendiri bagi mereka dan perusahaan, salah satunya sangat membantu dalam penyebaran informasi. Seperti halnya, pesan sampai lebih cepat pada khalayak, biaya operasional penyebaran lebih murah dan menjangkau lebih banyak ruang cakupan.

Praktisi meyakini kemampuan media sosial yang dibangun atas fondasi teknologi internet dapat menembus batas ruang dan waktu sehingga informasi yang disebarkan oleh perusahaan memiliki kemungkinan yang lebih besar dalam menjangkau publik yang lebih luas dan seketika secara real time. Praktisi menyambut baik kehadiran media sosial karena dengan kemajuan perkembangan teknologi sangat membuka peluang untuk interaksi yang lebih baik dan penyebaran informasi yang lebih cepat dengan jangkau yang lebih luas. Pemanfaatan media sosial diakui oleh praktisi dapat secara efektif menekan pengeluaran biaya untuk penyebaran informasi dibanding melalui media massa. Bersamaan dengan hal itu juga berdampak kepada keefektifan dalam hal tenaga dan waktu yang dimiliki oleh praktisi.

Selain itu keunggulan lainnya dari media sosial yang dirasakan adalah membantu praktisi dalam mendapatkan umpan balik yang lebih cepat. Tidak hanya itu saja namun juga praktisi mengatakan bahwa respon yang didapat melalui media sosial lebih besar dibanding dengan penyebaran informasi melalui media konvensional Lebih lanjut juga dikatakan bahwa menurutnya melalui media sosial juga memberikan kemudahan akses bagi perusahaan berkomunikasi publiknya begitu juga 
sebaliknya publik dapat dengan lebih mudah berhubungan dengan perusahaan secara langsung tanpa perantara. Akses dalam hal ini menekankan pada terbukanya kesempatan bagi publik untuk berinteraksi langsung dengan perusahaan tanpa perantara. Media sosial memungkinkan terjadinya interaksi dua arah antara perusahaan dengan publik secara seketika di saat itu juga sehingga membuka peluang pada aktifitas komunikasi yang lebih baik. Kemudahan akses ini tentu memberikan manfaat yang baik pada perusahaan dalam menunjang terbangun hubungan yang baik dengan publik.

Praktisi berpendapat bahwa yang menjadi kunci penting dalam mengelola media sosial adalah pada perencanaan strategis mengenai konten informasi yang akan disebarluaskan , kepada publik. Penyebaran informasi harus bersifat konsisten dan berkelanjutan namun konten-konten tersebut harus terorganisir dengan baik, agar setiap harinya konten tersebut terus mengisi akun media sosial dan tidak terjadi kekosongan. Untuk memastikan keberlanjutan konten informasi maka dibutuhkan suatu strategi pemetaan yang perlu dilakukan oleh praktisi. Kunci lain yang juga praktisi sarankan adalah setiap praktisi harus dapat mengenal karateristik setiap media sosial yang digunakan, karena pada dasarnya mereka memiliki karateristik yang berbeda. Dengan mengenal karateristik masing-masing media sosial akan membantu praktisi dalam memanfaatkannya secara lebih efeketif dạn efisien. Lebih jauh lagi bila menggunakan berbagai aplikasi media sosial berbeda tersebut maka integrasi antara satu media sosial dan lainnya juga wajib perlu dijadikan suatu perhatian utama. .

Beberapa kendala juga dialami oleh para praktisi dalam mengelola media sosial, secara umum hal ini disebabkan oleh media sosial yang merupakan salah satu perkembangan teknologi komunikasi di era baru dan masih perlu banyak usaha untuk lebih mendalaminya. Kendala yang dihadapi salah satunya adalah kurangnya dukungan dari pihak pimpinan perusahaan terhadap pemanfaatan media sosial. Praktisi mengungkapkan bahwa pemanfaatan media sosial sering kali terkendala oleh pihak manajemen perusahaan yang belum terbuka pada kemajuan perkembangan teknologi sehingga mereka memutuskan untuk tetap melakukan kegiatan penyebaran informasi dengan cara konvensional. Menurut praktisi terdapat kecenderungan pihak manajemen perusahaan merasa enggan dan ragu serta memiliki kekhawatiran akan dampak tak terduga yang mungkin terjadi dan membahayakan posisi perusahaan karena kehadiran media sosial. Praktisi mengungkapakan hambatan yang dirasakan hingga kini adalah karena media sosial merupakan hal yang baru maka pihak manajemen masih dalam proses tahap belajar mengenal dan beradaptasi sehingga masih dibutuhkan waktu untuk terus bergelut dalam memahaminya dan membiasakan diri dalam mengelolanya.

Pemahaman para pemimpin perusahaan mengenai media sosial yang masih awam juga tak jarang memberikan kendala proses pengembangan pemanfaatan media sosial, seperti terbatasnya ruang gerak bagi praktisi untuk memberikan inovasi yang dapat mengoptimalkan fungsi media sosial. Kendala berikutnya yang dialami oleh praktisi adalah mengenai disintegrasi pada pengelolaan media sosial khususnya dalam keserasian konten informasi. Tak jarang perusahaan menggunakan lebih dari satu aplikasi media sosial dan menyerahkan tugas pengelolaan tidak dikelola oleh satu divisi yang sama, yakni divisi operasional dan divisi media 
relations. Hal ini tentu membawa dampak yang kurang baik bagi perusahaan karena dapat menimbulkan kebingungan pada publik mendapatkan informasi yang berbeda dari perusahaan.

Pengelolaan media sosial merupakan penugasan baru yang menjadi tanggung jawab bagi praktisi. Selain menjadi tantangan bagi keterampilan teknis praktisi juga secara tidak langsung menambah beban pekerjaan praktisi. Ditambah lagi sifat media sosial yang selalu online 24jam membawa dampak pada bertambahnya tanggung jawab pekerjaan pada praktisi dengan waktu kerja yang ikut bertambah. Sehingga hal ini menimbulkan kendala lainnya yang berkaitan dengan kebutuhan adanya staf pendamping bagi para praktisi yang bekerja secara individu mengelola media sosial. Beberapa di antara praktisi mengakui dengan merekrut staf khusus akan membantu mereka dalam penugasan pengelolaan media sosial dan tetap fokus dalam mengerjakan akan membantu mereka.

\section{Pemanfaatan Media Sosial pada Praktisi}

\section{a. Mempertahankan Identitas Organisasi/ Branding}

Praktisi menyatakan bahwa media sosial membawa keuntungan tersendiri bagi kegiatan branding, praktisi dapat memberikan berbagai informasi mengenai identitas perusahaan kepada khalayak dengan tujuan untuk meningkatkan brand awareness pada publik. Disamping itu pula media sosial dapat membantu praktisi dalam membangun image perusahaan dan melihat respon publik kepada perusahaan. Praktisi menyatakan lebih lanjut bahwa kegiatan branding tidak hanya dilakukan terus memberikan informasi mengenai identitas perusahaan saja namun juga mencakup kegiatan evaluasi melibatkan respon publik mengenai positioning perusahaan dan mensegmentasi pasar. Menurut sebagian besar praktisi juga berpendapat bahwa disamping melakukan branding keberadaan media-sosial juga membantu dalam kegiatan pemasaran produk dan promo event perusahaan. Lebih jauh lagi praktisi dapat memantau respon yang diberikan publik melalui media sosial baik kepada perusahaan ataupun kegiatan pemasaran yang dilakukan. Media sosial juga merupakan salah satu media pendukung yang digunakan untuk mendongkrak kunjungan pembaca pada website perusahaan.

\section{b. Mengontrol Perkembangan Isu dan Krisis}

Praktisi juga sudah mengakui bahwa kehadiran media sosial juga dapat dimanfaatkan untuk mengetahui isu yang sedang berkembang di sekitar wilayah operasional perusahaan mereka. Praktisi menyatakan bahwa dengan kehadiran media sosial mereka dapat melakukan monitoring mengenai perkembangan isu serta tren yang terjadi di masyarakat. Monitoring isu akan membantu perusahaan dalam mengantisipasi berbagai ancaman yang dapat berdampak kurang baik bagi perusahaan sehingga praktisi dapat memberikan konfirmasi untuk meredam isu yang sedang berkembang. Lebih jauh praktisi menyatakan media soail juga dapat berfungsi sebagai media untuk menggalang dukungan emosional pada publik yang bermanfaat bagi kelangsungan hidup perusahaan.

\section{c. Pelaksanaan CSR}

- Praktisi menyatakan bahwa sejauh ini media sosial juga digunakan untuk menginformasikan kegiatan-kegiatan CSR dan kegiatan sosial yang dilakukan oleh 
perusahaannya. Praktisi juga menyatakan bahwa dengan memanfaatkan media sosial perusahaan dapat memantau serta memancing respon publik terhadap berbagai kegiatan sosial dan CSR yang dilakukan perusahaan sehingga dapat menjadi pertimbangan dalam merencanakan di kegiatan selanjutannya. Selain itu praktisi juga memanfaatak media sosial sebagai salah satu media dalam melakukan aksi kampanye sosial dan mempersuasi publik untuk ikut berpartisipasi melakukan hal yang sama.

\section{d. Berhubungan Dengan Publik}

Berdasarkan pada wawancara dengan praktisi mereka meyakini olehnya bahwa media sosial dapat memfasilitasi terbangunnya hubungan dengan publik yang lebih baik dengan cara-cara yang baik dan benar. Selain itu media sosial juga dimanfaatkan oleh praktisi sebagai media dalam penyampaian masukan bagi publik kepada perusahaan. Media sosial juga dimanfaatkan oleh perusahaan sebagai salah satu media yang dapat digunakan oleh konsumen untuk menyampaikan masukan dan kritikan. Dari monitoring kritik dan saran maka menjadi pertimbangan tersendiri bagi perusahaan untuk dapat mengeluarkan kebijakan berkaitan dengan merespon kebutuhan pelanggan. Karena dengan memperhatikan saran dan kritik pelanggan maka akan membangun dan mengembangkan perusahaan dan memberi kepuasaan kepada pelanggan dalarn menciptakan hubungan dengan mereka.

Media sosial dapat membantu perusahaan dalam berhubungan dengan konsumennya dengan lebih baik, seperti semakin cepat dalam merespon keluhan dan kritik dari konsumen. Selain itu perusahaan juga dapat lebih tanggap dalam menjawab pertanyaan konsumen yang berkaitan mengenai produk maupun jasa yang ditawarkan. Perusahaan juga semakin lebih mudah dalam memantau hal-hal yang dibutuhkan dan diharapkan oleh konsumen sehingga dapat menjadi pertimbangan perusahaan dalam membentuk kebijakan di masa depan. Pelaksanaan monitoring terhadap segala feedback yang diberikan oleh konsumen akan dikaji kembali oleh pihak manajemen perusahaan untuk memperbaiki kelemahan-kelemahan yang ada serta untuk memberikan respon balik yang tepat kepada konsumen. Lebih jauh lagi dengan melakukan interaksi dengan konsumen melalui media sosial maka perusahaan dapat melakukan segmentasi produk dan konsumen. Kehadiran media sosial diakui oleh praktisi memberikan kemudahan dalam memonitoring perilaku konsumen.

\section{e. Kesimpulan}

Keseluruhan praktisi dalam penelitian ini menyambut baik dan antusias dengan kehadiran media sosial. Mereka juga meyakini bahwa media sosial merupakan cara baru dalam penyebaran informasi dan berhubungan dengan publiknya. Media sosial dapat menyampaikan informasi lebih cepat serta menjangkau khalayak lebih luas dengan biaya yang lebih murah. Praktisi juga mengakui bahwa respon publik dari kegiatan penyebaran informasi melalui media sosial lebih banyak didapatkan dan dapat direspon seketika oleh pihak perusahaan. Media sosial memberikan kemudahan akses bagi perusahaan maupun publik dalam berkomunikasi secara langsung dan bersifat dua arah.

Di lain pihak media sosial merupakan hal baru yang masih perlu banyak dipelajari oleh praktisi lebih dalam. Media sosial menjadi tantangan bagi praktisi dalam mengasah kemampuan mereka sebagai seorang profesional. Beberapa kendala juga dihadapi oleh para praktisi 
dalam mengelola media baru ini, salah satunya seperti pandangan pihak perusahaan yang masih tertutup menghadapi perkembangan teknologi baru. Disamping itu juga mengakibatkan bertambahnya beban kerja dan waktu kerja pada praktisi yang berdampak pada ketersediannya staf pendamping pengelola media sosial serta terjadinya ketidakselarasan konten informasi pada aplikasi media sosial yang digunakan oleh perusahaan. Namun menurut praktisi kendala-kendala tersebut dapat diatasi dengan terus berusaha untuk mengenal media sosial dan memberikan pengarahan pada pihak manajemen perusahaan mengenai media sosial. Praktisi juga melakukan strategi pemetaan dalam proses penciptaan dan penyebaran informasi untuk mengantisipasi kesalahan pada konten yang akan disebarluaskan.

Hasil pada penelitian ini menunjukan bahwa keseluruhan praktisi menggunakan media sosial untuk kegiatan branding perusahaan dan penyebaran informasi mengenai promo perusahaan. Disamping itu sebagian besar di antara mereka juga memanfaatakan media sosial untuk membangun hubungan dengan publik dengan cara yang lebih baik dari sebelumnya. Media sosial digunakan sebagai salah satu sarana penyampaian saran dan kritikan bagi publik kepada perusahaan. Beberapa diantara praktisi juga sudag mulai memanfaatkan media sosial dalam pemantauan perkembangan isu dan komunikasi krisis serta penyebaran informasi mengenai kegiatan tanggung jawab sosial perusahaan serta kampanye-kampanye sosial yang dilakukan perusahaan. Diharapkan untık kedepannya para praktisi akan semakin dapat memanfaatakan media sosial lebih optimal dari sebelumnya dalam menunjang kegiatan public relations perusahaan. 


\section{Daftar Pustaka}

Cutlip, Scott M., Allen H.Center., Glen M. Broom. (2006). Effective Public Relation: Ninth Edition. New Jersey: Pearson Prentice Hall.

Franklin, Rob., Mike Hogan., Quentin Langley., Nick Mosdell., Elliot Pill. 2009. Public Relations. London: Sage Publications Inc

Grunig, J. E. 1992. Excellence in Public Relations and Communication Management. New Jersey: Lawrence Erlbaum Associates, Publishers

Grunig, J. E. 2009. Paradigms of global public relations in an age of digitalisation. PRism 6(2): http://praxis.massey.ac.nz/prism on-line journ.html

Kelleher, Tom. 2007. Public Relations Online; Lasting concepts for changing media. USA: Sage Publications

Lindic, Jaka. 2006. "How do Corporations Use Internet for Public Relations", BLED Proceedings Paper

McLennan, Asleigh., \& Gwyneth V.J. 2010. Social Networks And The Challenges for Public Relations. Asia Pacific Public Relations Journal, Vol.11
Moleong, Lexy J, 2005, Metode Penelitian Kualitatif Edisi Revisi, Rosda Karya, Bandung

Reitz, Amy. 2012. Social Media's Function in Organizations: A Functional Analysis Approach. Global Media Journal Volume 5, Issue 2, pp.41-56

Solis, Brian., Dreirdere Breakenridge. 2009. Putting The Public Back In Public Relations: How Social Media is Reinventing The Aging Business of PR. USA: Pearson Education

Valentini, Chiara., Dean Kruckeberg. New and Social Media: The Meaning and The Use of Communication Technologies in Public Relations. 2011. Research Conference. Global for Public Relations. (http://pure.au.dk//portal/files/452 45616/New and Social Media The Meaning and the Use of Communication Technologies in _Public_Relations.pdf)

Watson, Tom., Paul Nobel. 2007. Evaluating Public Relations: a best practice guide to public relations planning, research and evaluation. London \& US: Kogan Page Limited. 